Discourse and Communication for Sustainable Education, vol. 12, no. 2, pp. 5-30, 2021

\title{
Promoting Environmental Citizenship Through Local Socio-Cultural Traditions in Science Education
}

\author{
Simo Häyrynen, Tuula Keinonen and Sirpa Kärkkäinen \\ University of Eastern Finland, Joensuu, Finland
}

\begin{abstract}
This article asks how the site-specific parameters of pro-environmental behaviour can be seen in educational doctrines and in the practices of science education, and what impact they have on the development of environmental citizenship. Environmental citizenship as an agent of change is key to sustainability transition. Our viewpoint is that a contextual resource doctrine provides a framework of people's environmental values, meaning both the capacity to fulfil the requirements of the doctrine and the ability to critically reflect it by rational-scientific arguments. Thus, place-specificity and sense of place should be highlighted in citizenship science education. In order to explain the multi-scalar nature of learning requirements, we apply the idea of 'trans-contextualisation' in science education. In the article we use examples which are derived from university students' favourite places reflecting sense of place as well as three cases, which start from the near secondary school students' environment and discuss local environmental issues. In this study we used qualitative and quantitative research methods. The results show that by promoting contextually sensitive environmental citizenship through Socio-scientific Issues (SSI) in science education, we could accelerate the transition to sustainable future. If cultural traditions, anecdotal and local knowledge are not incorporated in the expert scientific knowledge, sustainability transition is constantly in danger for remaining an isolated activity in the shadow of resource realism.
\end{abstract}

Key words: environmental citizenship, cultural variation, place-based science education, national resource doctrines, trans-contextualisation

\section{Introduction}

Environmental citizenship is widely seen as a way, to achieve more intensive sustainability transition than before. According to Dobson (2010), environmental citizens would act as the advocates or models of sustainable ways of life for the rest of the population. However, while decision-makers often focus on the technical aspects of sustainability (energy reduction, compact settlement structures), the ecological and cultural parameters in the construction of environmental citizenship remain less researched. It is assumed here that different societal contexts - ecological, economic and socio-cultural realities produce different nature-relations which are more or less institutionalised, yet embedded in traditional place-specific ways of life. 
We see that it would be no use for sustainability goals to blame locals if they are accustomed to living according to traditional nature-relations. Consequently, localities provide different 'ideal subjects' for environmental citizenship and for learning objectives. It means that cultural traditions, anecdotal and local knowledge need to be incorporated in the expert scientific knowledge when such ideals are sought. Environmental issues are often related to complex scientific issues. These issues are challenging in public and policy debates causing controversies and requiring citizens to be able to incorporate both scientific understanding and broader cultural, political, and social factors. Citizens need scientific literacy in deciding behaviours around these environmental issues that allows them to investigate scientific understanding with these extraneous factors (Kirby, 2021; Zeidler et al., 2005). Good practices in education are needed to promote contextually sensitive environmental citizenship. Therefore, this article asks whether and how the site-specific parameters of pro-environmental behaviour can be seen in educational doctrines and in the practices of science education, and what impact they may have on the development of environmental citizenship.

\section{Environmental Citizenship, Education, and Resource Doctrines}

Environmental citizenship has been seen to consist of an understanding of ecological issues (Gabrielson \& Cawley, 2010), the rights and responsibility of citizens (Clarke \& Agyeman, 2011), and action to promote positive and sustainable human interactions with the environment (Berkowitz et al., 2005). As such it would be an ideal agent of change. There are a number of theoretical considerations on how environmental citizenship is politically constructed: liberal, republican, populist, multicultural, pluralist, cosmopolitan, globalist (Hadjichambis \& Reis, 2020). It makes it complex to develop consistent transnational practices of environmental behaviour or to foster environmental citizenship by educational perspectives. Environmental citizenship is partially an outcome of environmental education. The point of departure here is that the promotion of an ecological attitude depends not only on the economic performance, political directives, or technological innovations of society. Nor is it solely dependent on the ecological reality of the community at stake. It is about the cultural-ecological essence of a community that applies and adopts environmental practices and constructs contextually adequate environmental behaviour (Devine-Wright, 2013). Unless developed in relation to a local natural resource tradition, environmental education may easily remain a separate and somewhat esoteric field of ethics. Thus, in order to achieve (scalarly appropriate) educational practices, it is important to identify and evaluate cultural links of ordinary nature relationships - and their most typical constellations within, for instance, attitudes and values of animal treatment, ecosystem services and built environment.

Environmental education and current science education approaches overlap in respect of contexts, approaches, and aims. We see science education as having an important role in promoting environmental citizenship. To promote environmental citizenship in science education, Iversen and Jónsdóttir (2019) use the term 'practising' and adhere to a perspective that enhances a collective approach and participation. Moreover, several environmental education researchers have previously stressed the action-competence approach to advocate active participation (Breiting, 2009; Jensen, 2002; Mogensen \& Schnack, 2010) and utilize local experience (Avery, 2013; Gratani et al., 2016; ReyesGarcia et al., 2010). 
Through critical inquiry, the pre-service teachers' ecological literacy evolved from a generalized to a place-specific understanding, particularly to the social, economic, political, and cultural intricacies of their energy-yielding system and the human roles within that system (Green et al., 2016). Through project participation, the pre-service teachers became more aware of their own values and the values of others, which prompted their sustained action on behalf of any environmental problem and they also indicated their professional commitment toward action-oriented environmental education by devising an educational policy and campaign.

Environmental education plays an important role in modern nature-relations but established contextual interplay with nature may create strong path dependencies for human behavior. Traditional resource extraction is a part of a regime of rules involving technologies, rationalities, and institutions, made intelligible by regimes of truth that organize understanding and experience, and mobilize consensus among people (Rose, 1999; Wilson et al., 2017). Official narratives frame the problem in ways that legitimize forms of actions and make other actions wrong or odd (Baviskar, 2003; Polleta et al., 2011). Such a natural resource doctrine does not directly define the actions of individuals or different sectors, but creates a framework in which the success of the doctrine leads functions, and others such as sustainability thinking or human rights issues, though publicly cherished, remain somewhat marginal in respect of the main goal. Categories of ideal environmental citizenship, thus, evolve with respect for natural resource doctrines in terms of both the capacity to fulfil its requirements, and the ability to reflect critically by scientific arguments. A critical reflexivity to natural resource activities that employ a large part of the community may call for extra courage.

As such, environmental citizens are made in a long and complex process of political socialization by the prevalent values of education, media, and popular culture (Cao, 2015). At the global level, high-carbon, fossil-fuel, or black/brown cultures have been hegemonic since the early $20^{\text {th }}$ century (Wilson et al., 2017). Such hegemony is never static because societies in which it influences and operates are not static - changes in knowledge, technology, political power relations, and natural environment cause pressures on hegemonic projects as well. In the long-sighted development, the fossil-fuel doctrine seems to be losing the battle for the souls of younger generations (Bulkeley et al., 2016; Jamison, 2002). However, many think that the transition is too slow or too insecure. It also means that even if technological development and political practices prove otherwise, individuals may still find their ideas of success and human progress from the earlier ideas of petro-civilization (based on the symbolic success of the fossilfuel life-style) (Wilson et al., 2017) and the neoliberal citizen (McGuigan, 2014).

Long-term symbolic governance of a natural resource imagery cannot be removed in a blink of an eye just because EU formal negotiations have reached some solution and the consultant speech changes accordingly. The peat industry has for a century been a great national project for Ireland, and aimed to break free of energy, economic and political dependence on the UK. When the peat industry and traditional turf-cutting in the Midlands region of Ireland were seriously questioned by the recent climate politics, it was hard to swallow for communities where the primary industry was located (Häyrynen et al., 2021). This means that in some cases the production of locally 'adaptable' environmental citizens is influenced by a sense of 'lost pride'. By combining local cultural traditions and other informal ways of learning with science education, a sense of inferiority in the face of global solutions can be prevented. 
What keeps some ideas of resource exploitations alive inside people's minds even if the rationale of an older hegemony is seriously questioned? How does the dominance of certain resource thinking still pass educational institutions and how could it be changed in different cultural contexts? What could facilitate a critical review of a strongly internalized natural resource doctrine? Can an answer be found from the hierarchies between different societal systems or sectors? A special highlight of the EU's 2030 Agenda lies in understanding the interconnection of systems and how changes in one system can have effect in others (Sulc et al., 2020). How can education for environmental citizenship take into consideration interwoven elements of natural resource doctrine and local knowledge? These interwoven developments are here approached through the ideas of science education and how it is integrated with the contextual development of natural resource doctrines.

\section{Citizenship Science Education - Place-Specificity, Trans-Contextualisation}

To find out how education for environmental citizenship can take into consideration interwoven elements of science education, natural resource doctrine and local knowledge, the use of society related science issues offer an appropriate forum. Science education can help students to become responsible citizens (Davies, 2004), and particularly by using societal-science issues. The science component of citizenship needs to be related to a critical perspective of the society in which we live, the values that sustain it, and the question of what can be changed (Hodson, 2003). Science education should facilitate participation in collective endeavours connected to science-related issues (Roth \& Lee, 2004). Science students practising environmental citizenship should address real-world issues that have environmental and scientific dimensions. If citizenship education is to be implemented and collaboration is sought between science education and citizenship education, then some sort of approach is necessary that is based on the similarity of purposes and processes of the two areas (Davies, 2004). We propose that the view dominating in the last decades that science education has been viewed as being 'education through the context of science' (European Commission, 2004, 2007) is a suitable perspective. Science is described as a tool that is 'contextualised in the problems that participants try to solve rather than decontextualised knowledge, with no immediate bearing to everyday life; knowledge is therefore emergent and situated rather than discrete and generalised' (Levinson, 2010, p. 100). To find the relevant contexts for the teaching is challenging for teachers. They need to possess contextual sensitivity to identify particularly site-specific (local) context for teaching.

The relation to natural resource doctrines provides optimal frameworks for the fact that issues which advance citizenship are essential elements of current science education implemented through different context-based approaches such as Socio-scientific Issues (SSI), Science-Technology-Society (STS), Science, Environment and Health (S|E|H), or Socio-Scientific Inquiry-Based Learning (SSIBL) approaches (Aikenhead, 1994; Gericke et al., 2020; Holbrook \& Rannikmae, 2017; Levinson, 2018; Zeyer \& Dillon, 2019). All these approaches seek to promote goals in science education related to general interest and public understanding with particular reference to: individual empowerment; intellectual capabilities such as critical thinking, logical reasoning/analytical skills, creative problem-solving and decision-making; national and global citizenship; socially responsible action by individuals; communication skills in a variety of forms; and providing 
skilled workforce for business and industry (Aikenhead, 1994, 2000; Holbrook \& Rannikmäe, 2017; Rannikmäe 2002). Dealing with SSI in real-world settings through out-of-school activities set in the students' local district is important for practising environmental citizenship (Iversen \& Jónsdóttir, 2019). The tensions between the practice of environmental citizenship and the cultural issues related to school science exist between working with ready-made-science, as students normally do, to dealing with science-inthe-making through SSI (Iversen \& Jónsdóttir, 2019). This is a promising finding, since SSI has the opportunity, to cover the transversal competence areas besides the subject's contents in the curriculum.

Context-based approaches generally proceed through several stages. The three stages: scenario, inquiry, and decision-making (Bonnett, 2002) are often used. Many scholars in environmental education such as Bonnett (2002) and Stables and Scott (2002) argue that scientific and technical solutions to the environmental crisis lack crucial elements and are therefore inadequate responses to the crisis. Chowdhury, Holbrook and Rannikmäe (2020) add the fourth stage - trans-contextualisation stage, to enhance awareness and involve active participatory approaches to controversial issues of a local, national, or global nature. The stage seeks to stimulate a sense of commitment to undertake actions beyond the school, leading to active informed citizens. The trans-contextualisation stage is based on a concern that an individual's decision-making is not connected to societal activity outside the classroom. The trans-contextualisation stage seeks to engage students in transferring their learning from school environment to the wider environmental, economic, social (at a local, national or global) arena, thus addressing the sustainable development of the society, especially through local tradition. In this way, formal education is systematically supplemented by informal learning in society such as traditional stories and anecdotes.

Several researchers emphasise that collaboration between science education and citizenship is not without challenges (Davies, 2004; Levinson, 2010). It is noted that cultural issues related to school science can make collaboration difficult. The out-ofschool activities and student assignments as SSI are important factors of promoting environmental citizenship in the students' local districts. Students practise environmental citizenship in science, as they are active participants in a political process in an environmental dimension, participate in debate within their groups in the classroom, train argumentation and interview in a real-world setting local decision-makers, contact the local media and contribute indirectly through different channels (Iversen \& Jónsdóttir, 2019).

Trans-contextualisation provides one solution for this because it takes SSI closer to multiscalarity. Sustainability transition is often perceived as a multilayered process. For instance, a multi-level perspective (MLP) to sustainability transitions understands transition dynamics as the exchange between macro-level socio-technological landscapes (urbanization, ideological frameworks), socio-technological regimes (methods of transportation or agriculture) and grass-root sustainability transitions (niches, cycling movements) (Geels et al., 2017). It is important to recognise that commonly shared goals may have very different interpretations at the local level (Häyrynen \& Hämeenaho, 2020). Context-based approaches in science education, particularly focusing on local issues, have similarities with place-based or site-specific approaches in environmental education. Place meanings are not only freely created through place-based experiences, but also conveyed by and emerged from discussions among educators and participants of environmental education. There is also a need for a more philosophical approach to 
the environmental crisis by combining emotions and feelings with ecological questions (Bonnett, 2002; Ontong \& Le Grange, 2014; Stables \& Scott, 2002).

\section{Local Issues Promoting Place-Based Education}

Nature-relations vary locally by the roles local community has in respect of resource doctrine. As such a national resource doctrine creates an umbrella for local resource communities and the construction of environmental citizenship with flavours of local identity. Educational systems/syllabi may occasionally combine ideas of nature exploitation with cultural forms (collective memories and local narratives) that increase the acceptability of dominant exploitation (hegemony) creating more or less institutionalised natural resource doctrines with their local specifications. It means that some localities may be more involved with the primary production of natural resources, some others with the transportation, export, energy provision, producing socio-ecological silence in relation to resource exploitation. Differing knowledge-regimes require locally sensitive science education.

Sense of place has become a commonly used factor in land and resource management (Kruger \& Jakes, 2003; Williams \& Stewart, 1998) and in community planning and design (Bott et al., 2006; Stevenson, 2005). Human geography's conception of a "sense of place" is consistent with environmental psychology's notion of place attachment. Place attachment represents an emotional or affective bond between a person and a particular place. From a psychological perspective, describing the meaning places have for people can be considered in terms of two place attachment indicators - place dependence and place identity. Place dependence refers to the relationship with a particular setting; it is a functional attachment. Place identity, an emotional attachment, refers to the psychological investment with a setting that has developed over time. Repeated visitation due to place dependence may lead to place identity. Place identity is predicted to directly influence specific Environmental Responsible Behaviour in a particular setting (Kudryavtsev et al., 2012; Semken, 2005).

Interest in sense of place has grown rapidly in recent years, with the concept extended from leisure and recreation to a wide range of applications and settings. The concept broadly describes human connection to places, including place attachment and place meaning (Farnum et al., 2005; Smaldone et al., 2005; Stedman, 2003). Place attachment refers to the emotional bonds between an individual and a geographic locale, or how strongly a person is connected to a place (Jorgensen \& Stedman, 2001; Low \& Altman, 1992; Raymond et al., 2010) whereas place meaning is the descriptive, symbolic meaning that people ascribe to a place (Smaldone et al., 2008; Stedman, 2008, 2016). Using place as a starting point in environmental education will enable students to understand the localness of environmental problems as well as their global-local connections (Ontong \& Le Grange, 2014).

Pedagogy of place originates from the specific attributes of a place; it is inherently multidisciplinary; it is inherently experiential; it reflects an educational philosophy which transcends 'learning to earn'; and it connects place with the self and the community (Woodhouse \& Knapp, 2000). Place-based pedagogies are needed so that the education of citizens might have some direct influence on the wellbeing of the social and ecological places that people inhabit (Gruenewald, 2003). Regarding the connection of self to place, a pedagogy of place shares some mutual ground with sustainability as a frame of mind (Ontong \& Le Grange, 2014). 
Place-based education provides a compelling educational approach that provides promise toward cultivating citizenship (Schild, 2016). Place-based educators (Gruenewald, 2003; Sobel, 2014) have been explicit in identifying deep emotions as significant aspects to consider when designing programmes for environmental learning. For them, emotional attachment to a place is a necessary aspect of getting people to work towards the betterment of the environment. In the study by Iversen and Jónsdóttir (2019), students reported that practical assignments in the district excited them. Looking forward to exploring SSI that concerned and was situated in their hometown was liked as well as getting knowledge from where they live and what is happening in the municipality. Students considered the assignment relevant. This is thus one way to make science education relevant, it helps students to become effective citizens in their societies (Stuckey et al., 2013), and perhaps to exceed locally strong norms.

This combination of practical and emotional attachment to place and particular nature-relation is here approached from the viewpoint of culture. Culture produces a 'relevance structure' based on knowledge, values and beliefs, which contains different and even contradictory tendencies. Culture is a composition of values and meanings, which are shared within certain, some clearly classified groups of people (Geertz, 1973). Culture is often represented by the cultural formations such as arts, literature and various forms of popular culture. Similarly, however, culture as a cognitive relevance structure/ cognitive regime is represented by educational strategies and discourses included in official documents such as curricula.

Environmental citizenship is expected to strengthen the awareness of cultural context. A sense of belonging to a specific place grows from some local seed, embedded in the ground, shaped by physiographic elements - the land, the water - gradually revealing the fabrics and artificially fabricate the landscape. These are cultural and societal traits that usually respect the balance and nature of each place (Sulc, 2020), fading perhaps away as the scales go up. However, it should be stressed that culture can sometimes be even harmful for sustainability goals, when incorporated into modern consumer-oriented values.

Landscape is a nature resource, providing opportunities for experiences of nature. Effective place-based science teaching must be informed not only by the sound scientific knowledge of the places of study but also by a respectful if not mutual understanding of the diverse meanings and attachments affixed to these places. These meanings and attachments provide context for the scientific knowledge, and enrichment of the senses of place of students and should be an expected learning outcome of a place-based science lesson, course, or curriculum (Semken, 2005). Sense of place or environmental sensitivity is the basis of environmental education. The most important experiences that define environmental sensitivity are childhood experiences in nature and of values held by the family, education (Smederevac-Lalic, 2020; see also de Souza, 2016). In place-based teaching, the most important sense of place to consider emerge as the personal meanings and attachments that exist between each student and the place or places offered as the context for the curriculum. Place and sense of place are concepts that have been defined and characterized thoroughly enough to be accessible to science educators. Sense of place - meaning and attachment, cognition, and affect - is in essence what place-based education is intended to teach. Such methods, which actively engage and enhance the sense of place of students and teachers, are highly appropriate for the earth, and ecological, and environmental sciences. 
Place-based science teaching focuses on local and regional environments and synthesizes different ways of knowing them, leveraging the sense of place of students and teachers. Place-based teaching has been advocated for its relevance and potential to attract underrepresented groups to science. The sense of place is a term used liberally but often differently in humanistic, sociological, geographic, and educational discourse (Feld \& Basso, 1996; Kincheloe et al., 2006; Ryden, 1993; Williams et al., 1998) to encapsulate connections among people and places. Many different meanings - for example, aesthetic, ceremonial, economic, familial, historical, political, and spiritual, as well as scientific - can accrue to the same place, evincing the spectrum of ways that individuals and communities know and experience that place. People also develop emotional attachments to meaningful places. The combined set of place meanings and place attachments, held by a person or a group, constitutes a functional definition of the sense of place (Brandenburg \& Carroll, 1995; Williams \& Stewart, 1998). This is because it is characterized by a relationship to some identifiable portion of the coincident natural and cultural landscapes, and furthermore that the sense of place is contextually bound, much like the overlapping concept of indigeneity (McKinley, 2007). However, these landscapes evolve, contextual boundaries are redefined, and the sense of place is socially negotiated (Casey, 1996).

\section{Indigeneous Sense of Place}

People in their daily local environments are often aware of environmental problems but it does not translate into social action. When facing complex and abstract scientific explanations, people may feel a sense of helplessness that leads to fear, ignorance, or the denial of the suggested environmental actions (Norgaard, 2011). The increasing predominance of large-scale systems has created clashes of scale, where the local level repeatedly conflicts with the uniformization and standardization from above (Eriksen, 2017 , p. 152). Many studies, however, emphasize the importance of indigenous knowledge as a component of adaptive capacity. Andean indigenous farmers, for instance, have become experts with climate uncertainty, and they have a rich set of indicators used for indigenous ways of predicting the weather, including plant and animal indicators as well as astronomical phenomena (Boillat \& Berkes, 2013, p. 21). If such indigenous knowledge can be incorporated into school science curricula, it provides familiar contexts within which to learn scientific concepts (Baquete et al., 2016). To illustrate potential outcomes of endemic, indigenous sense of place in environmental issues, our examples deal with localized sites. We follow the idea of Keinonen and De Jager (2017) that valuing student's contextual cultural capital (the sociocultural context in which they grew up) improves the engagement of students with science education. It means that science education needs to address the roots of local cultural representations (rituals, stories, commemorials) by following the flow of culture and thought through networks and in various spatial places. However, when scientific explanation differs epistemologically from locally-specific cultural explanation, as in the case of many natural phenomena, it may cause afore-mentioned resistance. Local norms of behavior may then end up normalizing macro-level policies of economic growth and promoting stagnation. Indigenous knowledge must be acknowledged as process, emphasizing ways of observing, discussing and interpreting new information (Boillat \& Berkes, 2013). 


\section{Towards Environmental Citizenship through Local Sociocultural Realities in Science Education}

The integration of place-based education and Socio-scientific Issues (SSI) approach in science education has the potential to promote environmental citizenship. In this section, we report what are Finnish students' favourite places reflecting sense of place (Bott et al., 2006; Kruger \& Jakes, 2003; Williams \& Steward, 1998), place meaning (Smaldone et al., 2008; Stedman, 2008, 2016) and finally place identity, and why students prefer these places. Then we report three SSI cases, which start from the near environment and discuss local environmental issue.

\section{Finnish Students' Close Interplay with Nature}

The study by Kukkonen et al. (2018), among Finnish university students ( $\mathrm{N}=458$ ) revealed that the enjoyment of nature and the intent of support for environmental activities are related; also related is the enjoyment of nature and ecological knowledge. Ecological knowledge leads to global concerns and some students who possess ecological knowledge, despite the relationship being weak, also perceive human dominance over nature. The relationship between different constructs is rather complex, however, the enjoyment of nature is an important factor for environmental actions and ecological knowledge. In the content analysis, seven categories of students' favourite places were identified (Table 1).

\section{Table 1}

Finnish University Students' $(N=458)$ Favourite Places

\begin{tabular}{lclc}
\hline Favourite place - categories & $\begin{array}{c}\text { Number of } \\
\text { statements }\end{array}$ & Favourite place - categories & $\begin{array}{c}\text { Number of } \\
\text { statements }\end{array}$ \\
\hline $\begin{array}{c}\text { Home } \\
\text { home or own room }\end{array}$ & $175(47 \%)$ & Greenery & $50(13 \%)$ \\
childhood home & 31 & forest & 26 \\
grandparent's place & 14 & hills & 8 \\
childhood home yard & 10 & a city park & 7 \\
home yard & 8 & field & 5 \\
some other's home & 3 & & 4 \\
home municipality & 1 & & \\
\hline Water & $72(19 \%)$ & Urban locations & $16(4 \%)$ \\
a lake shore & 37 & a city & 10 \\
a sea shore & 14 & childhood city & 3 \\
a lake, pond, mire, or river & 10 & suburban/fringe are & 2 \\
near water & 8 & & 376 \\
an island & 3 & & \\
\hline Summer cottage & $63(17 \%)$ & Total & \\
\hline
\end{tabular}

The favourite place represents sensitivity for environment, and it has received a lot of attention in the studies in the fields of environment sciences, psychology, and geography. The results in study indicated that university students' most general favourite place is a 
social place such as home, their own room, childhood home, or summer cottage. Ecological places such as forests or lakes were also favoured as well as cultural settings (urban location, recreation area, city park). Students identified themselves in places representing national resources such as forest and water. They are specific for the Finnish landscape and culture. The students explained why these places are their favourite places and the results are shown in Table 2.

\section{Table 2}

Finnish University Students' Reasoning for Their Favourite Places

\begin{tabular}{lclc}
\hline \multicolumn{1}{c}{ Reasoning } & $\begin{array}{c}\text { Number of } \\
\text { reasoning }\end{array}$ & \multicolumn{1}{c}{ Reasoning } & $\begin{array}{c}\text { Number of } \\
\text { reasoning }\end{array}$ \\
\hline Restful/calm/peace & $112(21 \%)$ & Near nature/in nature & $28(5 \%)$ \\
Relaxation/relaxing & $55(10 \%)$ & Silence & $24(4 \%)$ \\
Safety/familiarity & $50(9 \%)$ & Beauty & $23(4 \%)$ \\
Actions/sport/moving/sauna & $49(9 \%)$ & Hails from & $21(4 \%)$ \\
People & $46(8 \%)$ & Space/back yard & $15(3 \%)$ \\
Landscape & $39(7 \%)$ & Other & $19(3,5 \%)$ \\
Be oneself & $32(6 \%)$ & & 546 \\
Memories & $28(5 \%)$ & Total & \\
\hline
\end{tabular}

The most common reason was that the place is restful, calm or that there is peace.

The lake has an important significance in my childhood because I lived on the lake. The lake is both calm and stirs to think.

The second category of reasons is relaxation.

I feel that I relax best on the water, listening to the nature and observing.

Students could mention both, restful and relaxation, therefore these themes are categorized in separate categories. Also experiences of beauty, freedom and escape from social pressures were reported.

Beautiful environment (home), where nice doing (e.g., sleeping) exists, pleasant and calm, no noise etc.

Favourite places appear to afford restorative experiences that aid emotion- and self-regulation processes which are basic to the development of place identity. Familiarity was also important, and for some students, people made the favourite place not the physical setting.

...not the place, but people with whom I am ...

...there is something to do and my nearest are there...

Landscape or view was important as well and that they could be there as they liked and be oneself so that nobody was looking. Memories constructed a favourite place which often is near nature and silent, but also beautiful.

Because it is an old timber house which is atmospheric. Particularly the cabin (tupa) is lovely. I love it when my mother makes a fire in the big baking oven. 
It was very often important where the student comes from. It defines the favourite place, being near the familiarity category. Other important factors were that the place is atmospheric and that there is fresh air. For some students was important the location of the place and for some that it was new.

The descriptions indicated emotional bonds between the students and a geographic locale, or how strongly the students are connected to a place, i.e., place attachment (Jorgensen \& Stedman, 2001; Low \& Altman, 1992; Raymond et al., 2010). Natural environments in general were seen as more restorative than many of the urban environments (Weber \& Trojan, 2018). In natural environments students concentrated on themselves indicating connection to the places such as a forest and the place had a meaning to them (e.g., a home) (Farnum et al., 2005; Smaldone et al. 2005; Stedman, 2008). Following these findings, the students described their connection to particular places, including place attachment and place meaning and finally feeling sense of place (Farnum et al., 2005; Smaldone et al., 2005; Stedman, 2003). It is in these circumstances that sustainability thinking can be overshadowed by local resource realism and drift into the above-mentioned isolated ethical reflection detached from everyday life.

To develop and apply goals for future sustainability, we must consider what people care about and what motivates them to engage in solving sustainability issues (e.g., Khumalo, 2021; Timoštšuk, 2016). Sense of place theory and methods provide a rich source of insights that, like the social-ecological systems perspective, assume an interconnected social and biophysical reality. Students were emotionally attached to favourite places, and developed over time, that they identified themselves in these places. Place identity is generally predicted to directly influence specific Environmental Responsible Behaviour at a particular setting (Kudryavtsev et al., 2012; Semken, 2005), and therefore students' place identity may influence their Environmental Responsible Behaviour.

\section{SSI Teaching-Learning Examples}

By studying university students' place attachment as a background, it could be imagined what kind of place-specific context could be relevant for lower secondary school students, since even younger students do probably not have as strong memories. As Davies (2004) claimed, there will be debates about the extent to which context-based science courses and scientific literacy courses can provide a valuable link with citizenship education. Citizenship is seen to be enhanced in science education, through SSI approach using local contexts. The Finnish core curriculum describes seven transversal competence areas. These epitomise the aims of education and reflect the competences needed in all spheres of life. Competence is constructed of knowledge, skills, values and will. One of the seven transversal competences is participation, involvement and building a sustainable future. The core curriculum therefore enhances teachers' willingness to create science teaching modules which promote a sustainable future. Based on previous experiences in science education intervention research internationally and nationally and particularly in the European Union MultiCO project, as well as findings in previous literature and favourite place studies, it is possible to believe that the use of site-specific local scenarios as a starting point in studying a particular science issue connects ecological and societal viewpoints in the consideration of the science issue. The MultiCO project (www.multicoproject.eu) sought to clarify how career-related scenarios in the context-based approach stimulate students and relate to educational gains related to working life skills and 
responsible citizenship. There are three good place-based practice intervention cases implemented in the MultiCO project. Since place-based education uses students' authentic experiences outside the classroom to personalize learning to their local area, it may help them to see how global issues are mirrored in their local communities and help them recognize their impacts on these places. The Finnish students possess ecological knowledge however this does not necessary lead to environmentally friendly activities (Kukkonen et al., 2018). Thus, there is a need to add an environmental citizenship component in science education. It is not possible to choose personal contexts for every student in the class neither teacher can use the most interesting context for all issues to be studied. It is important to try to find relevant, site-specific, local issue related to the subject to be studied.

The methodology of these three case studies (Kang et al., 2018) consists of qualitative and quantitative methods. The data was collected before, during and after the interventions through several methods. First, the lessons were observed by a researcher. Second, the students answered, after the scenario stage, a scenario evaluation questionnaire (Kang et al., 2018) including 28 Likert items, all of them in 4-point scale. The questionnaire was developed for the MultiCO project. Third, data were collected by interviewing the teachers after the intervention. Fourth, the students were interviewed after the intervention to get more detailed information about how they relate to the scenario and the intervention. The interviews were analysed using inductive and deductive content analysis. The questionnaire was analysed by using the SPSS Programme and some examples of descriptive statistics are presented in the results.

\section{Case 1: Energy}

The topic of the SSI interventions in the physics course was energy in three groups (in total 50 students) taught by three teachers. The planning of the interventions started when teachers, industry stakeholders from three different companies, and MultiCO researchers met in Fortum, a local heat plant using natural resource peat. The following items were discussed: heating plant, the pyrolysis process unique in the plant, careers in plant and the possibilities for the students' visits. The teaching-learning process of one teacher with his 18 students is presented here.

In the scenario stage, the student group visited a small energy plant which is situated in the neighbourhood of the school and is owned by a cooperative. The entrepreneur presented the plant and also visited the school continuing the presentation. Several careers related to energy production were discussed. This took one lesson (45 minutes). The teacher asked the students to build an organization chart of a district heating plant. The chart should present the staff in the organization and their tasks. Next, the teacher showed a photograph of the district heating plant of Fortum Oy and told that the group would visit this plant the next lesson and get more information about the plant, jobs and work in the heating plant. In the inquiry stage, the student group watched a video on district heating plan, the teacher clarified that the students should focus on the burning process. The group discussed why the district heat is a good thing (ecological, societal, ethical, and technological issues) and finally students selected the most important thing for discussion. The teacher distributed a chart showing the structure of the heating plant to the students. He told about energy production and the two heating plants were compared. The teacher gave the task to examine how the staff of Fortum is educated. At first the students listed their perceptions and then started in pairs to search information 
on the Internet using the process chart. The teacher collected the organization chart on the screen. Next the careers in the heating plant were discussed. The students found several careers presented in the production of heat. They were asked to create career cards for two careers. These activities were implemented in 90 minutes (two 45 minutes lessons). After the visit (90 minutes) careers in the plant were discussed. Teacher also told them about technology industry. He drew an organization chart on the screen. The whole heat production process was discussed with careers in different phases and skills needed in these careers. The students placed themselves into the chart according to their interests. They searched information about 'their career', wrote a card about them and placed it in the chart. The stages of teaching are shown in Table 3.

\section{Table 3}

Stages of Energy Teaching Module Based on SSI

\begin{tabular}{lll}
\hline \multicolumn{1}{c}{\begin{tabular}{c}
\multicolumn{1}{c}{ First } \\
Out-of-school visit
\end{tabular}} & $\begin{array}{c}\text { Second } \\
\text { Out-of-school visit }\end{array}$ & \multicolumn{1}{c}{ Inquiries } \\
\hline $\begin{array}{l}\text { Visit in small heating plant just in the } \\
\text { neighbourhood of the school; PP presen- } \\
\text { tation of the plant. Careers are discussed } \\
\text { in the local plant and visit of the entre- }\end{array}$ & $\begin{array}{c}\text { Visit in peat } \\
\text { energy plant. }\end{array}$ & $\begin{array}{l}\text { Search information on } \\
\text { careers, preparation of career } \\
\text { cards and placing them in }\end{array}$ \\
$\begin{array}{l}\text { preneur in school; entrepreneur, forester, } \\
\text { truck driver, forest machine contractor, }\end{array}$ & $\begin{array}{l}\text { Inquiry is aimed to famili- } \\
\text { arize with careers. }\end{array}$ \\
$\begin{array}{l}\text { wood splitting producer, automation } \\
\text { mechanics. Also co-operative action was } \\
\text { discussed. The students worked with }\end{array}$ & $\begin{array}{l}\text { Energy topics is studied } \\
\text { teacher-centred. Careers and } \\
\text { careers also later in the intervention. }\end{array}$ & $\begin{array}{l}\text { energy production are inter- } \\
\text { twined. }\end{array}$ \\
\hline
\end{tabular}

What choices did the teacher make regarding SSI teaching, how did he see the sustainability issue and what are his reasons for the choices? The teacher decided to associate intervention with the visit to the Fortum district heating plant. The energy plant was a local context for studying energy issues. The plant may be relevant to students' lives and interests at present, or to situations students may encounter in the future in their lives; it is related to technological development because for example the pyrolysis process, and it has a link to industry (Bennet et al., 2007). Peat is a controversial and current issue and is as important for livelihood even if people are prone to be more sustainable (Häyrynen et al., 2021). Science was used as a tool when students studied careers, carried out inquiries concerning energy, and discussed sustainability issues (Levinson, 2010). To find the relevant context for the teaching is challenging for teachers. They need to possess contextual sensitivity to identify particularly site-specific (local) context for teaching. The context in this teaching-learning process was agreed particularly during the stakeholder meeting held at the plant. The teacher chose his own way to carry out the intervention which is the teacher's right based on their autonomy. The teacher with his students also chose a smaller energy plant in the neighbourhood of the school. This plant is owned by a cooperative and the entrepreneur presented the plant. In this way, the teacher could also integrate entrepreneurship education in science education. Immediately after the visit to the plant, the teacher invited the school where the entrepreneur continued the presentation because the teacher found this to be a useful resource to widen students' understanding of the cooperation Several careers related to energy 
production were discussed. The teacher chose to use an organisation chart presenting careers in different stages of the heat production process which was their main point in working. This idea came from the video and from the visit to Fortum.

All three teachers creating energy intervention perceived the visit in Fortum as very important in the planning phase. When they discussed with the head of the plant, they developed ideas about how to work with their students. One teacher was more interested in the pyrolysis process, others in careers. At the beginning, teachers had the feeling that it is very difficult to create an energy scenario which links with Fortum and their teaching about energy. However, when they worked together in their schools, they found very creative ways for integration and were successful to create an effective entity (Ekborg et al., 2013). The students were very interested when they heard that they would visit the heat energy plant. Obviously the out-of-school visits were the most important thing which engaged students in the learning process. For some students, the visit was indeed interesting because of the topic and the heat plant as energy producer, and they perceived learning from professionals very important.

Visit to Fortum because I learned a lot there.

Visit to Fortum and got to learn about electricity, heat and water production and transfer.

Some of the students pointed out learning from professionals.

Visit to Fortum and learning about the topic from those who know the issue.

Visit, because professionals told (mostly new) things.

Concerning the working life skills, most of the students agreed that during the intervention they understood what skills are needed in the careers considered. The students listed skills such as electricity skills, skills to use machines, ability to concentrate, not to rush, precision, not to fuss around, caution, interest, biology, math, language skills, organization skills, co-operation, intelligence, managing skills, patience, initiative, and not to be afraid of high places.

The energy module in science education has the potential to enhance environmental citizenship in the following ways: the SSI module promotes students' understanding of the use of nature resource (ecological), its production (technological, societal), and the role of professionals in the production (societal). This module could be enlarged by collective decision-making concerning the role of peat energy and participation in debate on energy issues.

\section{Case 2: Road Salt}

Road salt scenario for chemistry course in the MultiCO project also is focused on a local issue. It is developed in Germany and used similarly with the same approach both in Germany and Finland. In this scenario the city manager in Bonn/Joensuu is reading emails that citizens have sent asking what she will do to prevent the damages road salt has caused. Road salt context was implemented in Finland by four teachers with 76 students in total. The implementation by one teacher with her students is introduced here. In total 7 lessons were used for the teaching-learning process.

The teacher applied the road salt scenario with open-ended inquiries related to chemistry and students worked on it for over one week. Students had to take responsibility 
to make the project successful as there were no ready-made instructions to follow for the inquiries. The teacher presented to the students the road salt scenario with the presentation (examples in Figure 1, more in www.multico-project.eu) and talked about the problems that road salt is causing. The slides were translated into Finnish but Bonn as a context was left. Teachers believed students are able to understand the situation also in another country. Discussions about scenario slides in class led to five research themes which were investigations how road salt affects 1) grass, 2) iron, 3) limestone, and 4 ) ice, and how 5) does road salt melt ice. These themes could be carried out with the equipment available in the classroom.

\section{Figure 1}

\section{Example Slides of the Scenario (created by the Bonn MultiCO team)}
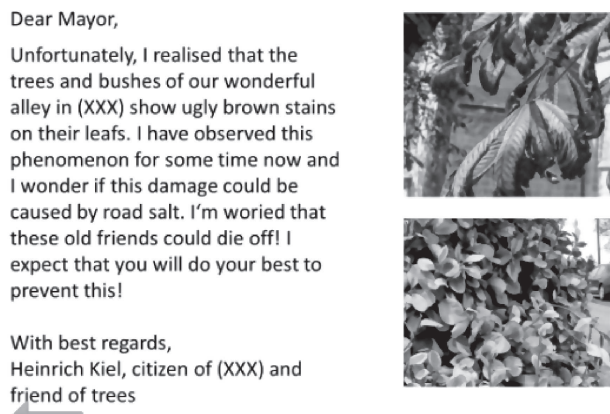

Dear Mrs. Mayor,

My name is Meinhard Karlson and I live in (XXX-suburb). I am a keen lover of the historic buildings in our region and only recently visited the Cologne Cathedral. There my wife and I noticed some damage in the floor panels ot the outer building. We assume that these damages could have been caused by road salt. We were wondering if our beautiful cathedral and the buildings of $(X X X)$ are at risk, too? Have you ever considered such a risk? My wife and me would very much appreciate your feedback on this matter.

Kindest regards,

Meinhard and Gerda Karlson

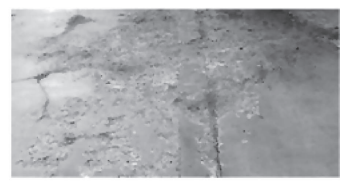

The teacher asked the students if they have had any experience of these issues, as road salt is very commonly used in Finnish culture during the long winters. Students had ideas about cars rusting and some general thoughts about environmental (ecological and ground water) issues road salt could cause. Then students had to figure out what equipment they need to investigate the formulated research themes. With guidance, the students figured how they could test the different situations with the solutions (aq) of road salt and the possible replacement by a chemical compound (Viaform). The discussion provoked students' personal interests and the teacher organized the students in small groups according to the students' wishes. Next, the five student small groups started to plan the inquiry and the hands-on activity. The teacher had prepared the materials for the students so they could focus on designing the experiments. The hands-on activity was implemented with open-ended problems which induced some problems for making accurate measurements. In the beginning the students had no ready-made templates to follow or fill in.

After the students had planned their experiments, they were given some questions they had to make sure to answer. The questions were the following: 1) What is the field of expertise of the research group?; 2) What is your experiment about?; 3) How did you carry out the experiment?; 4) Which salt solution (aq) do your results support?; 5) What are your recommendations for the city manager? The students carried out their experiments for the whole week, making notes and continuing the experiments. One group continued watering the grass with different salt solutions and water and others made observations about the progress of the experiments. All student groups answered the questions and 
presented their work in front of the class. The results were a bit inconsistent, yet the student small groups were able to react to each other's presentations and make arguments based on the presented information. Recommendations for the city manager was seen to correspond action and participation in society to form a trans-contextualisation stage (Chowdhury et al., 2020).

The project had open-ended experiments and it also required the responsibility from the students to carry out the tasks during the week. The students showed effort and persistence to finish their project in time and to formulate arguments. The teacher gave instructions to the student small groups as they faced difficulties but in general the working was student-centred. The students clearly gained new knowledge from the scenario ( $86 \%$ agreed) but they were not willing to learn more ( $83 \%$ disagree) about it. The scenario was not personally important for the students, and they were not willing to learn more about the topic. The use of road salt is connected with the damages in trees and pollution of ground water (ecological issue) and on the other side with traffic safety (social and cultural issues). Some students considered the use of salt from an ecological point of view.

I: What do you learn about this?

S1: Well, at least what kind of the disadvantages of road salt can be. But on the other hand, it can be good if something else is so much worse or terribly worse in nature.

I: Is this information relevant to you personally at the moment?

S!: No, I'm not quite because I don't think so much about it.

S2: Well, maybe salting is not the worst of problem in the world right now. I have sometimes wondered why the trees can go brittle or why the buildings are deteriorating, so this example explained it.

I: If you're thinking about your community/municipally perspective? S1: Well, I don't know about municipal affairs, but at least Viaform does not harm nature, so salt can be a good option.

S2: I like my own living environment and I like to know what's going on here and what kind of road salt is used.

The teacher expected that the site-specific and very local issue would interest students, but this was not the case. Students' perceptions were similar in both countries where the module was implemented (Germany and Finland). These cases in both countries show that the teacher careful needs to consider the context, to possess contextual sensitivity to fit the context properly in students' life and culture.

\section{Case 3. Pedestrian Crossing}

The Pedestrian crossing - scenario relates to the use of space as an immaterial nature resource, to the behaviour and attitudes of drivers in a site-specific case, to traffic safety in Europe as social-cultural issue and walking versus bicycling from the viewpoint of sustainability. Students practice participation in society in a trans-contextualisation stage (Chowdhury et al., 2020; see Varis et al., 2018).

The pedestrian crossing had disappeared near the school. In this teaching-learning module for the physics course, the students should argue why they need to get the 
pedestrian crossing back near the school. The students had a chance to participate and influence local decision-making concerning their own lives. Two student small groups measured the speeds of vehicles on the street. One small group interviewed students in the classes as well as teachers to get information about how students and teachers behave when they need to cross the street. The fourth group had the task to plan questions for the head of municipal engineering, collect the results from the other groups, and write a document for the authority. During the last lesson, the municipal engineer visited the class, introduced himself, and told them about his work and the challenges the position holds. The students proceeded to the questions they had prepared. The students presented the results of speeding cars and students who ran across the road and the municipal representative strongly suggested that the students should make an initiative to the municipality for restoring the pedestrian crossing. Finally, students wrote an initiative letter to the municipality requesting painting of the pedestrian crossing.

In the learning process, students exchanged knowledge and tools with others and produced knowledge for the community in the form of a citizen's initiative leading to an action by the municipality: the painting of a pedestrian crossing. The students were keen on exercising participation and producing information through inquiries for their citizen initiative. After the intervention, most of the students expressed their willingness to participate in society and act as active citizens, they perceived that they had the means and opportunities, as well as the possibility to find support to participate and influence. Students were willing to participate particularly in their local communities. Students perceived that they learned and gained competences while participating. Students acknowledged knowledge as a base of the decision, which may promote perceived value of physics and associated careers. Students also highlighted collaboration and shared experiences, which may create engagement and participation concerning the scientic issues to which they relate. The students perceived that they acquired new knowledge about the topic $(89 \%)$ as well as about careers $(74 \%)$. The scenario was found very easy to understand and was enjoyable. However, they did not feel that the scenario is related to their future careers, and it did not prompt them to be interested to study more. The site-specific scenario was interesting and raising interest to study, and particularly participation in society. This scenario had more societal relevance than ecological.

In these three examples, out-of-school activities and student assignments being an SSI are important factors of promoting environmental citizenship (Iversen \& Jónsdóttir, 2019). The topics were connected to the assignments being located in students' own district.

\section{Discussion of Findings}

Through selected empirical case studies, we aim to respond to how site-specific parameters are identified and utilized in educational doctrines and science education. We argued that science education has the potential to locally develop more sensitive environmental citizens through the SSI approach (cf. Kirby, 2021; Chowdhury et al., 2020; Levinson et al., 2017). The review of the case studies from this viewpoint shows that the shift from a general environmental understanding to a place-specific understanding keeps both teachers and students interested in the topic and reinforces the emotional sense of place as an important transmitter of sustainability thinking. Contextually sensitive environmental citizenship, as the articles show, can connect local cultures, ways of life 
and place-specific social organization with the general aims of science-education. Hence, it helps to localize the ethical questions of the exploitation of nature.

Apart from what was considered in the teaching-learning process, the understanding of ecological issues related to peat and the responsibility of citizens in choosing what and how they use energy could have been discussed to promote environmental citizenship and respectively in the road salt module, the use of salt from more broader viewpoints (Carke \& Agyeman, 2011; Gabrielson \& Cawley, 2010). In relation to the framework introduced by Berkowitz et al. (2005), the modules offer possibilities to develop environmental citizenship through several components. In the context of energy, road salt and pedestrian crossing there are possibilities: to understand key social, economic, cultural, and political systems and develop critical thinking skills and ecological systems using sound ecological thinking; to become aware of personal values with respect to the environment particularly in relation to energy sources; to develop practical wisdom and skills for decision-making and acting with respect to the environment.

The nature of the ecologically sustainable future creates new challenges for science education. Self-evidently the limits of ecological processes to renew natural resources need to be taken into account. However, in communities, sustainability orientation depends on particular socio-economic constructions of human/nature-relation and resource exploitation. One challenge we noted when we viewed practical educational trends was that sustainability transition is constantly in danger of remaining an isolated activity in the shadow of resource realism. However, context-based science learning activities encouraged students to explore their own perceptions of ecological, economical, societal and cultural perspectives. When mundane local phenomena (traffic arrangements, energy plants) are presented together with science-based environmental perceptions, it is easier to see the perceptions as universal rather than esoteric expert talk. Thus, educational doctrines have to be integrated with the site-specific parameters to cope with strong resource realism.

Because cultural variation produces different 'ideal subjects' of environmental citizenship in relation to contextual resource doctrines and their critical reflection, place sensitivity is an elementary part of modern environmental science education. Place-specificity is a crucial element in this analysis. Ideas tested in the article encourage us to state that familiar area helps students upgrading the level of action to support sustainability and increase critical thinking in relation to traditional resource doctrines better than with a separate sustainability sector. Site-specific teaching examples and place-based basis for education reason the contextual nature of environmental citizenship science education. In the scenario with a pedestrian crossing, participation in a trans-contextualisation stage is seen as an example of the viewpoint for considering sustainability targets set in EU Green Deal and UN SDG's or the challenges in national resource doctrines and local reconsideration of nature (Häyrynen et al., 2021).

The three SSI modules introduced here offer a possibility for a collective approach and participation (Iversen \& Jónsdóttir, 2019) or for action competence (Breiting, 2009; Jensen, 2002; Mogensen \& Schnack, 2010; Schusler et al., 2017). Writing to the municipality in the pedestrian crossing module caused an effect, painting of the pedestrian crossing. The module was connected to the school and the environmental issue in the local district, and students' action was also published in the local newspaper (Jensen, 2002). In the road salt module, writing to the city manager was fictive and maybe therefore not so interesting to students. Teachers' understanding evolved from a generalized 
to a place-specific understanding in all modules, particularly in regard to the social, economic, political, and cultural respects. It can be concluded that through project participation, students became more aware of their own values and the values of others (interviews in pedestrian crossing scenario) and teachers indicated their professional commitment toward action-oriented science education (Green, 2016).

We agree with Cao (2015) that environmental citizens cannot be prepared in a short teaching-learning module. It is a long and complex process. Science education and how it is integrated with the contextual natural resource doctrines can however develop environmental citizenship if SSI issues are discussed regularly with students such as resource extraction, technologies, rationalities, and institutions, mobilizing consensus among students (Rose, 1999; Wilson et al., 2017). Science education in the three modules presented facilitated participation in collective endeavours connected to sciencerelated issues (Roth \& Lee, 2004). The modules included real-world issues, although in the road salt case with the fictive context, which had environmental and scientific dimensions; approaches shared the similarity of purposes and processes (Davies, 2004). The example issues here could be easily studied through SSI (particularly pedestrian crossing), STS (particularly energy, Ratcliffe \& Grace, 2002), SIElH (particularly road salt), or SSIBL approaches (Aikenhead, 1994; Holbrook \& Rannikmäe, 2017; Gericke et al., 2020; Levinson, 2018; Zeyer \& Dillon, 2019). The modules sought to promote goals in science education related to general interest and public understanding but also to individual empowerment, creative problem-solving and decision-making, and socially responsible action by individuals (Aikenhead, 1994, 2000; Rannikmäe, 2002; Vesterinen et al., 2016). Energy and pedestrian crossing modules included out-of-school activities set in the students' local district being important for practising environmental citizenship (Iversen \& Jónsdóttir, 2019).

The modules had three stages; scenario, inquiry, and decision-making (Bolte et al., 2012). The final action in the scenario road salt (email to city manager) and pedestrian crossing (a letter to municipality) are the trans-contextualisation stage in the learning process (Chowdhury et al., 2020). This stage sought through collective actions, to stimulate a sense of commitment to undertake unied actions beyond the school, leading to active informed citizens. Formal secondary school education should systematically be supplemented by informal learning in society. The approach presented to integrate science education and environmental citizenship education had challenges as Davies (2004) and Levinson (2010) have argued. Curriculum issues related to different subjects in school can make collaboration between subject teaching difficult. The transversal competences modules offer an excellent possibility to implement environmental citizenship in science education.

\section{Conclusion}

Our findings suggest that promoting environmental citizenship through SSI in science education accelerate the multi-scalar transition to an (ecologically) sustainable future. This is particularly important because most of the Finns already live in urban areas. Environmental protection is governed by national programs, strategies and legislation. Land use and planning creates the preconditions for a high-quality and vital environment. But there is a need to provide keys to making sustainable choices and decisions (see also Algurén, 2021). Environmental citizenship is widely seen as a way to achieve a more 
intensive sustainability transition than before. By integrating environmental citizenship components regularly in science education which is included in the curricula in all countries, the transition can be accelerated. With the aid of specially designed science education materials it is possible to foster environmental citizenship as locally-specific agents of change. It helps to analyse a current local community's progress towards sustainability, identify actions and discuss direct and indirect environmental behaviours and promote working with local stakeholders.

\section{Acknowledgments}

European Network of Environmental Citizenship (ENEC) COST-action (CA 16229).

\section{Author Contributions:}

Conceptualization, S.H., S.K. and T.K.; investigation, S.K. and T.K.; writing original draft preparation, S.H., S.K. and T.K.; writing - review and editing, S.H., S.K. and T.K., funding acquisition, T.K. All authors have read and agreed to the published version of the manuscript.

\section{Funding:}

The science education examples have been implemented in the project funded by the European Union's Horizon 2020 research and innovation programme under grant agreement No 665100, the work was also supported by the Academy of Finland (286733).

\section{References}

Aikenhead, G. S. (1994). What is STS science teaching? In J. Solomon \& G. S. Aikenhead (Eds.), STS Education International Perspectives on Reform. New York, USA: Teacher's College Press.

Aikenhead, G. (2000). STS science in Canada. From policy to student evaluation. In D. D. Kumar, \& D. E. Chubin (Eds.), Science, Technology, and Society. A Sourcebook on Research and Practice (pp. 49-89). New York, USA: Kluwer Academic.

Algurén, B. (2021). How to bring about change - a literature review about education and learning activities for sustainable development. Discourse and Communication for Sustainable Education, 12(1), 5-21.

Avery, L. M. (2013). Rural science education: Valuing local knowledge. Theory Into Practice, 52, 28-35. doi: 10.1080/07351690.2013.743769

Baquete, A. M., Grayson, D., \& Mutimucuio, I. V. (2016). An exploration of indigenous knowledge related to physics concepts held by senior citizens in Chókwé, Mozambique. International Journal of Science Education, 38(1), 1-16.

Baviskar, A. (2003). For a cultural politics of natural resources. Economics and Political Weekly, 5051-5055.

Bennet, J., Lubben, F., \& Hogarth, S. (2007). Bringing science to life: A synthesis of the research evidence on the effects of context-based and STS approaches to science teaching. Science Education, 91, 347-370. https://doi.org/10.1002/sce.20186 
Berkowitz, A. J., Ford, M. A., \& Brewer, C. A. (2005). A framework for integrating ecological literacy, civics literacy, and environmental citizenship in environmental education. In E. A. Johnson, \& M. J. Mapping (Eds.), Environmental education and advocacy: Changing perspectives of ecology and education (pp. 227-266). Cambridge, UK: Cambridge University Press.

Boillat, S., \& Berges, F. (2013). Perception and interpretation of climate change among Quechua farmers of Bolivia: Indigenous knowledge as a resource for adaptive capacity. Ecology and Society, 18(4), 21. https://doi.org/10.5751/ES-05894-180421

Bolte, C., Streller, S., Holbrook, J., Rannikmae, M., Hofstein, A., Mamlok Naaman, R., \& Rauch, F. (2012). Introduction into the PROFILES Project and its philosophy. In C. Bolte, J. Holbrook, \& F. Rauch, F. (Eds.), Inquiry-based Science Education in Europe: Reflections from the PROFILES Project (pp. 31-41). Klagenfurt, Austria: Alpen-Adria-Universität Klagenfurt. http://www.pef.uni-lj.si/profiles/objave/ PROFILES\%20Book\%20final_October2012.pdf

Bonnett, M. (2002). Education for sustainability as a frame of mind. Environmental Education Research, 8, 9-20. doi: 10.1080/13504620120109619

Bott, S. E., Banning, J., Wells, M., Haas, G., \& Lakey, J. (2006). A sense of place: A framework and its application to campus ecology. College Services, 6, 42- 47.

Brandenburg, A. M., \& Carroll, M. S. (1995). Your place or mine? The effect of place creation on environmental values and landscape meanings. Society and Natural Resources, 8, 381-398. https://doi.org/10.1080/08941929509380931

Breiting, S. (2009). Issues for environmental education and ESD research development: Looking ahead from WEEC 2007 in Durban. Environmental Education Research, 15, 199-207. doi: 10.1080/13504620902807584

Bulkeley, H., Paterson, M., \& Stripple, J. (Eds.) (2016). Towards a cultural politics of climate change: Devices, desires and dissent. Cambridge, UK: Cambridge University Press.

Cao, B. (2015). Environment and citizenship. London, UK: Routledge.

Casey, E. S. (1996). How to get from space to place in a fairly short stretch of time: Phenomenological prolegomena. In S. Feld, \& K. H. Basso (Eds.), Senses of place (pp. 13-52). Santa Fe, USA: School of American Research Press.

Chowdhury, T. B. M., Holbrook, J., \& Rannikmäe, M. (2020). Adressing sustainable development: Promoting active informed citizenry through trans-contextual science edcation. Sustainability, 12, 3259. doi: 10.3390/su12083259

Clarke, L., \& Agyeman, J. (2011). Shifting the balance in environmental governance: Ethnicity, environmental citizenship and discourses of responsibility. Antipode, 43, 1773-1800.

Davies, I. (2004). Science and citizenship education. International Journal of Science Education, 26, 1751-1763. doi: 10.1080/0950069042000230785

Devine-Wright, P. (2013). Think global, Act local? The relevance of place attachments and place identities in a climate changed world. Global Environment Change, 23, 61-69. doi: 10.1016/j.gloenvcha.2012.08.003

de Souza, M. (2016). The spiritual dimensions of education - addressing issues of identity and belonging. Discourse and Communication for Sustainable Education, 7(1), 125-138.

Dobson, A. (2010). Environmental citizenship and environmental behavior: Rapid research and evidence review. London, UK: Sustainable Development Research Network. 
Ekborg, M., Ottander, C., Silfver, E., \& Simon, S. (2013). Teachers' experience of working with socio-scientific issues: A large scale and in depth study. Research in Science Education, 43, 599-617. doi: 10.1007/s11165-011-9279-5

Eriksen, T. H. (2017). Overheating: An anthropology of accelerated change. London, UK: Pluto-Press.

European Commission. (2004). Europe needs more scientists. Report of the High Level Group on Human Resources for Science and Technology in Europe. https://ec.europa.eu/commission/presscorner/detail/en/IP_04_444

European Commission. (2007). Science education now: A renewed pedagogy for the future of Europe. https://www.eesc.europa.eu/resources/docs/rapportrocardfinal.pdf

Farnum, J., Hall, T., \& Kruger, L. E. (2005). Sense of place in natural resource recreation and tourism: An evaluation and assessement of reasearch findings. Recreation \& Tourism Initiative. General Technical Report. https:/www.fs.fed.us/pnw/pubs/ pnw_gtr660.pdf

Feld, S., \& Basso, K. H. (Eds.) (1996). Senses of place. School of American Research Advanced Seminar Series. Santa Fe, USA: School of American Research Press, pp. 91-135.

Gabrielson, T., \& Cawley, R. M. (2010). Plain member and citizen: Aldo Leopold and environmental citizenship. Citizenship Studies, 14, 605-615. https://doi.org/10.1080/ 13621025.2010.506721

Geels, F., Sovacool, B. K., Schwanen, T., \& Sorrell S. (2017). The socio-technical of low carbon transitions. Joule, 1, 463-479. https://doi.org/10.1016/j.joule.2017.09.018

Geertz, C. (1973). The interpretation of cultures. NY: Basic Books.

Gratani, M., Sutton, S. G., Butler, J. R. A., Bohensky, E. L., \& Foale, S. (2016). Indigenous environmental values as human values. Cogent Social Sciences, 2, 1185811. doi: 10.1080/23311886.2016.1185811

Green, C., Medina-Jerez, W., \& Bryant, C. (2016). Cultivating environmental citizenship in teacher education. Teaching Education, 2, 117-135. doi: 10.1080/10476210. 2015.1043121

Gericke, N., Huang, L., Knippels, M. C., Christodoulou, A., Van Dam, F., \& Gasparovic, S. (2020). Environmental citizenship in secondary formal education: The importance of curriculum and subject teachers. In A. Hadjichambis, P. Reis, D. ParaskevaHadjichambi, J. Ĉinĉera, J. Boeve-dePauw, N. Gericke, \& M.-C. Knippels (Eds.), Conceptualizing environmental citizenship for $21^{\text {st }}$ century education (pp. 19321). Cham, Switzerland: Springer.

Gruenewald, D. A. (2003). The best of both worlds: A critical pedagogy of place. Educational Researcher, 32, 3-12. https://doi.org/10.3102/0013189X032004003

Hadjichambis, A., \& Reis, P. (2020). Introduction to the conceptualisation of environmental citizenship. In A. Hadjichambis, P. Reis, D. Paraskeva-Hadjichambi, J. Cinĉera, J. Boeve-dePauw, N. Gericke, \& M.-C. Knippels (Eds.), Conceptualizing environmental citizenship for $21^{\text {st }}$ century education (pp. 1-13). Cham, Switzerland: Springer. https://doi.org/10.1007/978-3-030-20249-1_1

Hodson, D. (2003). Time for action: Science education for an alternative future. International Journal of Science Education, 25, 645-670. https://doi.org/10.1080/ 09500690305021 
Holbrook, J., \& Rannikmae, M. (2017). Context-based teaching and socio-scientific issues. In K. S. Taber, \& B. Akpan (Eds.), Science education. New directions in mathematics and science education (pp. 279-294). Rotterdam, Netherlands: SensePublishers. https://doi.org/10.1007/978-94-6300-749-8_21

Häyrynen, S., \& Hämeenaho, P. (2020). Green clashes: Cultural dynamics of scales in sustainability transitions in European peripheries. Palgrave Communications, 6, 90. https://doi.org./10.1057/s41599-020-0472-x

Häyrynen, S., Devery, C., \& Banerjee, A. (2021). Contested bogs in Ireland. A viewpoint on climate change responsiveness in local Culture. In G. Martinez (Eds.), Culture and resilience in relation to climate-change. Perspectives from Europe (pp. 69-96). Cham, Switzerland: Palgrave Studies in Climate Resilient Societies, Palgrave \& Macmillan. https://doi.org/10.10007/978-3-030-58403-0

Iversen, E., \& Jónsdóttir, G. (2019). 'We did see the lapwing' - practising environmental citizenship in upper-secondary science education. Environmental Education Research, 25, 411-421. doi: 10.1080/13504622.2018.1455075

Jamison, A. (2002). The making of green knowledge. Environmental politics and cultural transformation. Cambridge, UK: Cambridge University Press.

Jensen, B. (2002). Knowledge, action and pro-environmental behaviour. Environmental Education Research, 8, 325-334. doi: 10.1080/13504620220145474

Jorgensen, B. S., \& Stedman, R. C. (2001). Sense of place as an attitude: Lakeshore owners' attitudes toward their properties. Journal of Environmental Psychology, 21, 233-248.

Kang, J., Keinonen, T., Simon, S., Rannikmäe, M., Soobard, R., \& Direito, I. (2018). Scenario evaluation with relevance and interest (SERI): Development and validation of a scenario measurement tool for context-based learning. International Journal of Science and Mathematics Education, 17(7), 1-221317-1338. https://doi.org/ 10.1007/s10763-018-9930-y

Keinonen, T., \& De Jager, T. (2017). Student teachers' perspectives on chemistry education in South Africa and Finland. Journal of Science Teacher Education, 28(6), 485-506. https://doi.org/10.1080/1046560X.2017.1378055

Kincheloe, J. L., McKinley, E., Lim, M., \& Barton, A. C. (2006). Forum: A conversation on "Sense of Place" in science learning. Cultural Studies of Science Education, 1, 143-160.

Khumalo, S. S. (2021). A descriptive analysis of the leadership practices of primary school principals in promoting sustainability through motivating teachers. Discourse and Communication for Sustainable Education, 12(1), 42-54.

Kirby, C.K. (2021). Determinants of undergraduates' environmental behavioral intentions and their links to socioscientific education. Interdisciplinary Journal of Environmental and Science Education, 17, e22231. https://doi.org/10.21601/ijese/9335

Kruger, L. E., \& Jakes, P. J. (2003). The importance of place: Advances in science and application. Forest Science, 49, 819-821.

Kudryavtsev, A., Stedman, R. C., \& Krasny, M. E. (2012). Sense of place in environmental education. Environmental Education Research, 18, 229-250.

Kukkonen, J., Kärkkäinen, S., \& Keinonen, T. (2018). Examining the relationships between factors influencing environmental behaviour among university Students. Sustainability, 10, 4294. doi: 10.3390/su10114294 
Levinson, R. (2010). Science education and democratic participation: An uneasy congruence? Studies in Science Education, 46, 69-119. https://doi.org/10.1080/ 03057260903562433

Levinson, R., Knippels, M. C., van Dam, F., \& Kyza, E. (Eds.) (2017). Science and society in education. Socio-scientific inquiry-based learning: Connecting formal and informal science education with society. https:/www.parrise.eu/wp-content/ uploads/2018/03/parrise-en-rgb.pdf.

Levinson, R. (2018). Introducing socio-scientific inquiry-based learning (SSIBL). School Science Review, 100, 31-35.

Low, S. M., \& Altman, I. (1992). Place attachment: A conceptual inquiry. Human Behaviour and Environment, 12, 1-12.

McKinley, E. (2007). Postcolonialism, indigenous students, and science education. In S. K. Abell, \& N. G. Lederman (Eds.) Handbook of research on science education (pp. 199-226). Mahwah, NJ, USA: Erlbaum.

McGuigan, J. (2014). The neoliberal self. Culture Unbound 2014, 6, 223-240. doi: https://doi.org/10.3384/cu.2000.1525.146223

Mogensen, F., \& Schnack, K. (2010). The action competence approach and the 'new' discourses of education for sustainable development, competence and quality criteria. Environmental Education Research, 16, 59-74. doi: 10.1080/13504620903504032, https://doi.org/10.1080/13504620903504032

Norgaard, K. (2011). Living in denial: Climate change, emotions and everyday life. Cambridge, UK: MIT Press.

Ontong, K., \& Le Grange, L. A. (2014). Role of place-based education in developing sustainability as a frame of mind. Southern African Journal of Environmental Education, 27, 27-38.

Polletta, F., Chen, P. C. B., Gradner, B. G., \& Motes, A. (2011). The sociology of storytelling. Annual Review of Sociology, 37, 109-130.

Rannikmäe, M. (2002). Science teachers change towards STL teaching. Journal of Baltic Science Education, 2, 75-81.

Ratcliffe, M., \& Grace, M. (2002). Science education for citizenship: Teaching socioscientific issues. McGrawn-Hill Education, UK: Open University Press.

Raymond, C. M., Brown, G., \& Weber, D. (2010). The measurement of place attachment: Personal, community, and environmental connections. Journal of Environmental Psychology, 30, 422-434. https://doi.org/10.1016/j.jenvp.2010.08.002

Reyes-García, V., Kightley, E., Ruiz-Mallén, I., Fuentes-Peláez, N., Demps, K., Huanca, T., \& Martínez-Rodríguez, M. R. (2010). Schooling and local environmental knowledge: Do they complement or substitute each other? International Journal of Educational Development, 30, 305-313. https://doi.org/10.1016/j.ijedudev.2009.11.007

Rose, N. (1999). Powers of freedom: Reframing political thought. Cambridge, UK: Cambridge University Press.

Roth, W.-M., \& Lee, S. (2004). Science education as/for participation in the community. Science Education, 88, 263-291.

Ryden, K. C. (1993). Mapping the invisible landscape: Folklore, writing, and the sense of place. Iowa City, USA: Univeristy of Iowa Press, p. 19.

Schild, R. (2016). Environmental citizenship: What can political theory contribute to environmental education practice? Journal of Environmental Education, 47, 1934. doi: 10.1080/00958964.2015.1092417 
Schusler, T. M., Krasny, M. F., \& Decker, D. J. (2017). The autonomy-authority duality of shared decision-making in youth environmental action. Environmental Education Research, 2, 23, 533-552. https://doi.org/10.1080/13504622.2016.1144174

Semken, S. (2005). Sense of place and place-based introductory geoscience teaching for American Indian and Alaska Native undergraduates. Journal of Geoscience Education, 53, 149-57.

Smaldone, D., Harris, C. C., Sanyal, N., \& Lind, D. (2005). Place attachment and management of critical park issues in Grad Teton National Park. Journal of Park \& Recreation Administration, 23, 90-114.

Smaldone, D., Harris, C. H., \& Sanyal, N. (2008). The role of time in developing place meanings. Journal of Leisure Research, 40, 479-504. https://doi.org/10.1080/ 00222216.2008.11950149

Smederevac-Lalic, M. et al. (2020). Knowledge and environmnetal citizenship. In A. Hadjichambis et al. (Eds.), Conceptualizing environmental citizenship for $21^{\text {st }}$ century education. Environmental Science Education 4 (pp. 69-82). https://doi.org/ 10.1007/978-3-030-20249-1_1

Sobel, D. (2004). Place-based education. USA: Connecting Classrooms \& Communities.

Stables, A., \& Scott, W. (2002). A quest for holism in education for sustainable development. Environmental Education Research, 8, 53-60. https://doi.org/10.1080/ 13504620120109655

Stedman, R. C. (2003). Is it really just a social construction? The contribution of the physical environment to sense of place. Society and Natural Resources, 16, 671-685.

Stedman, R. C. (2008). What do we "mean" by place meanings? Implications of place meanings for managers and practitioners. In L. E. Kruger, T. E. Hall, \& M. C. Stiefel (Eds.), Understanding concepts of place in recreation research and management (pp. 71-82). General Technical Report PNW-GTR-744. Portland, Oregon, USA: U.S. Department of Agriculture Forest Service Pacific Northwest Research Station [online] URL: https://www.treesearch.fs.fed.us/pubs/29924

Stedman, R. C. (2016). Subjectivity and social-ecological systems: a rigidity trap (and sense of place as a way out). Sustainability Science, 11, 891-901. http://dx.doi.org/ 10.1007/s11625-016-0388-y

Stedman, R. C., \& Beckley, T. M. (2007). If we knew what it was we were doing, it would not be called research, would it? Society and Natural Resources, 20(10), 939-43.

Stevenson, D. (2005). Cultural planning in Australia: Texts and contexts. Journal of Arts Management, Law and Society, 35, 36-48.

Stuckey, M., Hofstein, A., Mamlok-Naaman, R., \& Eilks, I. (2013). Themeaning of 'relevance' in science education and its implications for the science curriculum. Studies in Science Education, 49, 1-34, doi: 10.1080/03057267.2013.802463

Sulc, I. et al. (2020). Societal issues and envieronmnetal citizenship. In A. Hadjichambis, P. Reis, D. Paraskeva-Hadjichambi, J. Ĉinĉera, J. Boeve-dePauw, N. Gericke, \& M.-C. Knippels (Eds.), Conceptualizing environmental citizenship for $21^{\text {st }}$ century education (pp. 49-65). Cham, Switzerland: Springer. https://doi.org/10.1007/9783-030-20249-1_1

Timoštšeuk, I. (2016). Primary science teaching - is it integral and deep experience for students? Discourse and Communication for Sustainable Education, 7(1), 82-99. https://sciendo.com/article/10.1515/dcse-2016-0006 
Varis, K., Jäppinen, I., Kärkkäinen, S., Keinonen, T., \& Väyrynen, E. (2018). Promoting participation in society through science education. Sustainablity, 10, 3412. 10.3390/ su10103412

Vesterinen, V. M., Tolppanen, S., \& Aksela, M. (2016). Toward citizenship science education: What students do to make the world a better place? International Journal of Science Education, 38, 30-50. http://dx.doi.org/10.1080/09500693.2015. 1125035

Weber, A. M., \& Trojan, J. (2018). The restorative value of the urban environment: A systematic review of the existing literature. Environmental Health Insights, 12. https://doi.org/10.1177/1178630218812805

Williams, D. R., \& Stewart, S. I. (1998). Sense of place: An elusive concept that is finding home in ecosystem management. Journal of Forestry, 95, 18-23. https:/www.fs.fed. us/rm/value/docs/sense_place_ecosystem_management.pdf

Wilson, S., Szeman, I., \& Carlson, A. (2017). On Petrocultures: Or, why we need to understand oil to understand everything else. In S. Wilson, A. Carlson, \& I. Szeman (Eds.), Petrocultures. Oil, politics, culture (pp. 3-20). Montreal \& London \& Chicago, Canada: McGill-Queen’s University Press.

Woodhouse, J. L., \& Knapp, C. (2000). Place-based curriculum and instructions: Outdoor and environmental education approaches. Charlestown, WV, USA: Eric clerringhouse on Rural Education and Small Schools.

Zeidler, D. L., Sadler, T. D., Simmons, M. L., \& Howes, E. V. (2005). Beyond STS: A research-based framework for socioscientific issues education. Science Education, 89, 357-377. https://doi.org/10.1002/sce.20048

Zeyer, A., \& Dillon, J. (2019). Science lenvironmentl health - the emergence of a new pedagogy of complex living systems. Disciplinary and interdisciplinary. Science Education Research, 1, 9. https://doi.org/10.1186/s43031-019-0014-9

Correspondence concerning this paper should be addressed to Simo Häyrynen, University of Eastern Finland, Joensuu, Finland. Email: Simo Häyrynen, simo.hayrynen@uef.fi 